$\left.\begin{array}{l}\text { Sournals } \\ \text { INTERNATIONAL JOURNAL OF } \\ \text { ORGANIZATIONAL LEADERSHIP }\end{array}\right) \begin{gathered}\text { INDUSTRIAL } \\ \text { MANAGEMENT } \\ \text { INSTITUTE }\end{gathered}$

\title{
Prediction of manipulation as a core part of social intelligence through selected personality traits in the context of business area
}

\author{
Anna Lelková ${ }^{*}$, Tatiana Lorincová ${ }^{2}$ \\ ${ }^{1,2}$ Prešov University in Prešov, Faculty of Management, Department of Managerial Psychology
}

\begin{abstract}
Keywords:

Manipulation, Personality

Traits, Business Area

The current research paper aimed to analyze the manipulation which is a core part of social intelligence through verification of predictive power personality traits, namely extraversion, agreeableness, conscientiousness, neuroticism, and openness to experience. The research sample consisted of 172 respondents, 84 men and 88 women of age between 23 to 57 (average age was 32, 47 and standard deviation was 8,197) working in business area. The

Received

13 August 2016 aim of the study was to analyze the predictive power of selected personality traits to manipulation. The research data were collected through NEO- Five Factor Inventory which measured the level of extraversion, agreeableness, aonscientiousness, neuroticism, and openness to experience by Costa and McCrae in Slovak translation by Hřebičková and Urbánek (2001) and MESI questionnaire which measured the level of manipulation by Frankovský and Birknerová (2014). Based on the confirmed aspects it was concluded that extraversion, openness to experience, and agreeableness have significant predictive power in predicting manipulation. Conscientiousness and neuroticism do not have significant

Correspondence: anna.lelkova@unipo.sk predictive power in predicting manipulation.
\end{abstract}

(C)AIMI Journals

The personality of the manager is the very important part not only because of the work environment, but also for his/her inner world and personal development. Personality of the manager is influenced through social and emotional intelligence, which plays necessary part in interpersonal relationships between manager and employees in the context of business area. The research paper analyzes manipulation as a core part of social intelligence which is related to personality of managers working in business area. 


\section{The Literature Review}

The recent studies define personality and personality traits in different ways. Personality is considered as a multidimensional construct. Following this, according to Mayer (1998) it is defined by the sufficient theories. The theories differentiate between individual components and describe their organization, mutual connection, and development (Lorincová \& Lelková, 2016). McAdams (1996) recommends three stages of personality system including personal features, strategies of managing, skills, values and life stories. McCrae \& Costa (1987) utilized these stages for creating "The Five-factor Personality System". The structure of personality systems affects personality parts of individual.

Five- factor model involves the general principles of features theories. Following this, an individual can be characterized on the comparatively enduring basis of thinking, feeling, and activities. Smekal (2002) make a list of those personal characteristics that best distinguish people. Considering the personal characteristics, extraversion refers to the energy from interacting with others, while introverts get their energy from within themselves; agreeableness alludes to individuals that are friendly, cooperative, and compassionate; conscientiousness states that people are reliable and prompt. Traits include being organized, methodic, and thorough; neuroticism which is sometimes called emotional stability, relates to one's emotional stability and degree of negative emotions; and openness to experience refers to people who like to learn new things and enjoy new experiences and usually score high in openness. Openness includes traits like being insightful and imaginative and having a wide variety of interests.

Oravcová (2004) argues that manipulation is one of the behavioral ways between people and defines it as an asymmetric interaction, where one side uses the other side to reach their own goals. It is a possible way how to influence other people, where their actions are the means of the manipulator to gain what they need. Manipulate behavior characteristics are motivated by personal success of manipulator; they are the goals that are hidden and behavior is camouflaged; also they take an advantage of other persons for own benefits of manipulator.

Spurný (1996) argues that manipulation is a way of the communication where we take action and change our idea under the emotional arguments and then we adjust to manipulators aims and objectives. He also defines other types of manipulative behavior like authoritative statements, referencing to the authority and explains "feel- sorry" strategy; he criticizes the mistakes of others but reminds everyone his credits; he defines arrogant and vile manipulation; and whether you like it or not, he knows what is the suitable and appropriate for you.

Edmüller and Wilhelm (2003) argue that manipulation is conscious and unconscious use of unfair procedures and behavior. The manipulation can occur in all types of communication such as the informational interview, consultation, management meeting, and friendly or critical conversation (Bozogáňová, 2014).

\section{Research Hypotheses}

The following research hypotheses guided the study:

$\mathbf{H}_{1}$ : Extraversion and neuroticism contribute to prediction of manipulation at significant level.

$\mathbf{H}_{2}$ : Agreeableness, conscientiousness, and openness to experience do not contribute to prediction of manipulation at significant level. 


\section{Method}

The main goal of the research is to analyze the manipulation through verification of predictive power of selected personality traits, namely extraversion, neuroticism, agreeableness, conscientiousness, and openness to experience. Research sample consisted of 172 respondents ages between 23 to 57 years (average age was 32.47 with standard deviation of 8.19 ). The proportionality of gender was uneven- the sample contained 84 men and 88 women. The research sample consisted of efficient and managing employees working in business sector. To this end, two self-reported questionnaires which measure manipulation and selected personality traits including extraversion, agreeableness, conscientiousness, neuroticism, and openness to experience came into use.

\section{NEO- Five Factor Inventory}

The Five-Factor Inventory is well-known methodology which measures personality traits created by McCrae \& Costa (1987) in Slovak translation by Hřebičková \& Urbánek (2001). The Five-Factor Inventory contains 34 items which are considered in 5-points scale (1strongly disagree, 5- strongly agree). The Five Factor Inventory consists of 5 personality factors or traits, namely extraversion, agreeableness, conscientiousness, neuroticism, and openness to experience.

Extraversion is distinguished by a series of items, namely excitability, sociability, talkativeness, assertiveness, and high amounts of emotional expressiveness. Agreeableness involve features including trust, altruism, kindness, affection, and other prosocial behaviors. People who are high in agreeableness are liable to have more cooperation while those low in this feature tend to be more competitive and even manipulative. Typical features of conscientiousness include high levels of thoughtfulness with favorable impulse control and goal-directed behaviors. Those high on conscientiousness tend to be well regulated and conscious of details.

Neuroticism is an attribute characterized by items including sadness, moodiness, and emotional instability. Individuals who are high in this trait are liable to experience mood swings, anxiety, moodiness, irritability, and sadness. Following this, those low in this attribute tend to be more stable and emotionally flexible. Openness to experience include characteristics such as imagination and insight and individuals high in this trait also tend to have a wide scope of interests. People who are high in this trait are liable to be more willing to take risks and be creative and people low in this trait are often much more traditional and may make forceful efforts with abstract thinking (McCrae \& Terraciano, 2005).

\section{MESI- Manipulation, Empathy and Social Irritability}

The MESI methodology is inspired by PESI methodology which was developed by Kaukiainen, Björkqist, Osterman, Lagerspetz, and Forsblom (1995). The original methodology was created for children of same age or their teachers to identify the level of perception of social intelligence. It contains 10 items within its internal consistency with Cronbach alpha of 0.90. The methodology MESI contains 21 items which are considered in 5-points scale (0never, 4- very often). Using factor analysis, three main factors, namely empathy, manipulation, 
and social irritability were extracted. Frankovský \& Birknerová (2012) extracted 3 factors of social intelligence including manipulation, empathy, and Social irritability.

Considering manipulation, the individuals with higher scores in this factor are able to convince others to do what they need. They know how to use them and convert them to stand on their side. They do not hesitate to use lies as a resource for their own benefit. Regarding empathy, the individuals with higher scores are aware of the ways of identifying intentions, feeling, and weakness of the others. They can adapt to new people and fulfil their expectations.

Social irritability expresses that people with higher score in this factor are irritated by communicating with other people, they are not able to adapt themselves, and cannot stand weakness. To this end, these factors by number and content match almost exactly with results of MESI methodology on Slovak research sample (Frankovský \& Birknerová, 2014). Extracted factors show $47.7 \%$ variance, which is acceptable and allowed to specify factors that was determined by Cronbach's Coefficient Alpha and the values are acceptable.

\section{Results}

The objective of the research was to analyze manipulation through verification of predictive power of selected personality traits including neuroticism, extraversion, openness to experience, agreeableness, and conscientiousness. Figure 1 presents the graphical display of regression standardized residual with dependent variable.

\section{Dependent Variable: Manipulation}

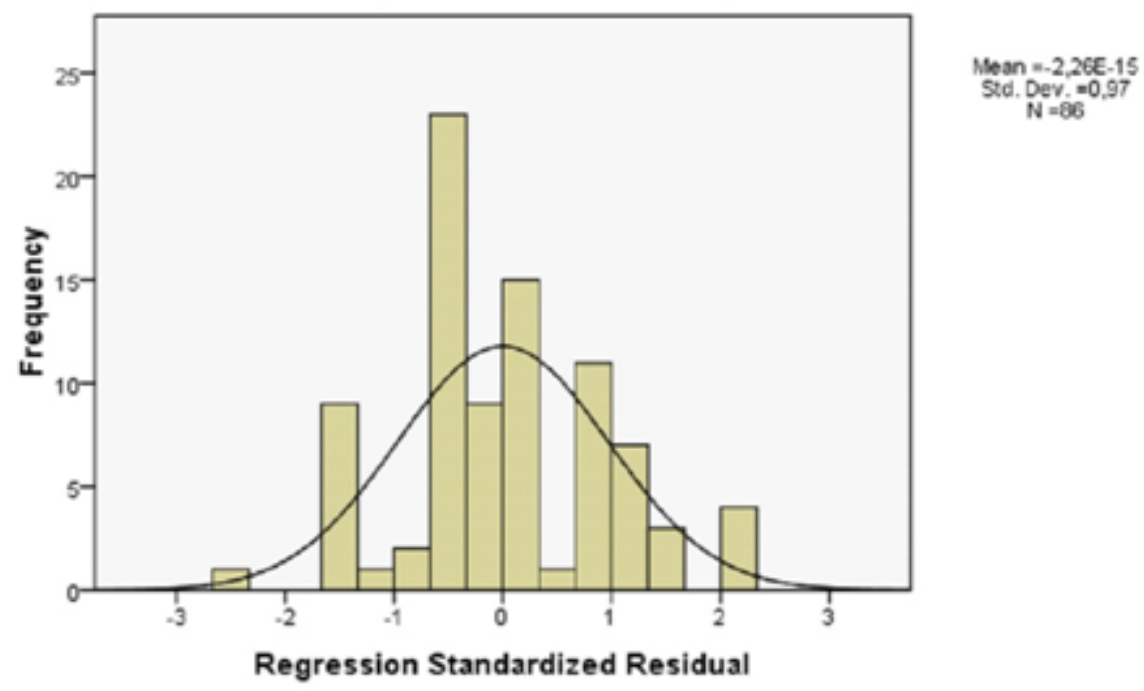

Figure 1. Graphical display of regression standardized residual with dependent variable: manipulation

The research results were processed in statistical program SPSS 17 and assessed by regression analysis. The histogram shows possibility for using linear regression because of the normality of collocation of regression standardized residual. Table 1 shows the predictive power of independent variables. 
Table 1

Prediction of manipulation through selected personality traits

\begin{tabular}{lccccc}
\hline Prediction of Manipulation & $\mathrm{B}$ & Std. Error & Beta & $\mathrm{T}$ & $\mathrm{p}$ \\
\hline Neuroticism & -0.215 & 0.206 & -0.127 & -1.046 & 0299 \\
Extraversion & 0.391 & 0.189 & 0.207 & 2.071 & 0.042 \\
Openness to Experience & 0.556 & 0.171 & 0.342 & 3.244 & 0.002 \\
Agreeableness & -0.385 & 0.167 & -0.280 & -2.303 & 0.024 \\
Conscientiousness & -0.124 & 0.206 & -0.064 & -0.604 & 0.548 \\
\hline
\end{tabular}

The Results revealed the predictive power of extraversion, openness to experience, and agreeableness to manipulation. Examined constructs explained $19.2 \%$ of prediction with $\mathrm{R}_{2}=0.192$. Extraversion had significant predictive power regarding $\beta=0.207$ and $p=0.042$. Openness to experience features with significant predictive power $\beta=0.342$ and $p=0.002$ and agreeableness features with significant predictive power $\beta=-0.280$ and $p=0.024$ explained the manipulation.

Hypothesis 1 was not confirmed because neuroticism did not dispose with significant predictive power to manipulation. Extraversion has significant predictive power and explained the influence to manipulation.

Hypothesis 2 was not confirmed, because agreeableness and openness to experience contribute with significant power to explanation of manipulation. It was assumed that agreeableness, conscientiousness and openness to experience did not contribute to prediction of manipulation in significant level. Conscientiousness does not contribute to prediction of manipulation in significant level due to conscientiousness features with low predictive power of $\beta=-0.064$ and $p=0.548$.

\section{Discussion and Conclusion}

Based on the confirmed aspects it was concluded that extraversion, openness to experience, and agreeableness have significant predictive power in predicting manipulation. On the other hand, conscientiousness and neuroticism do not have significant predictive power in predicting manipulation. Detection of personality traits in the context of manipulation which plays an important part in the concept of social intelligence had reason. A trait is considered as a temporally stable and cross-situational individual difference. Currently the most popular approach among psychologists for studying personality traits is the Five-Factor Model or Big Five dimensions of personality. The five factors were derived from factor analyses of a large number of self and peer reports on personality-relevant adjectives and questionnaire items. The following are some of the important characteristics of the five factors. First, the factors are dimensions not types; so people differ incessantly on them with most people falling in between the extremes. Second, the factors are firmly fixed over a 45-year period starting in young adulthood (Soldz \& Vaillant, 1999). Third, the factors and their particular aspects such as genetic are heritable at least in part (Jang, McCrae, Angleitner, Riemann, \& Livesley, 1998; McCrae, Costa, \& John, 1998). Fourth, the factors possibly had adaptive value in a prehistoric environment (Buss, 1996). Manipulation is very important part of social intelligence and influences manager's behavior and interpersonal relationships. The influence of selected 
personality traits (Big five model) is related to social intelligence, to the core part of manager's social intelligence which is manipulation.

Extraversion disposed with significant predictive power to prediction of the level of manipulation. Extraversion is fundamental part of personality and it is assumed that extraversion influenced manipulation. Explanation of the significant predictive power of extraversion hides in Machiavellianism in terms of interpersonal manipulation. On the other hand, people showing high levels of Machiavellianism (Christie, 1970) are distinguished by interpersonal manipulation including the use of flattery and deceit, as well as by aloof, cynical, and traditionally amoral viewpoints selected to develop their own aims/interests (Fehr, Samsom, \& Paulhus, 1992; McHoskey, 1995; Štefko \& Krajňák, 2013). It can be supposed that Machiavellian individuals can simply read the minds of others and understand social situations which they can strongly handle in the service of their own innate motivations (Fehr et al., 1992; Jones and Paulhus, 2009). Individuals also dispose with high level of interpersonal communication which is associated with high level of extraversion. This is the first clarification of research outcome which offers an idea of Machiavellian individuals. It means that high level of extraversion predicts Machiavellian individuals with high level of manipulation.

Results showed that openness to experience and agreeableness have significant predictive power to manipulation. The results are not consistent with hypothesis, because it is assumed that agreeableness, conscientiousness, and openness to experience do not contribute to prediction of manipulation at significant level. An individual with a high level of agreeableness in a personality test has characteristics such as being warm, friendly, and tactful. They normally have an optimistic perspective of human nature and get along well with others. Openness to experience is described through the drive for cognitive exploration of inner experience and it is the personality trait that is most frequently related to creativity. A person scoring high in conscientiousness generally tends to have a high level of self-discipline. These individuals prefer following a plan to acting spontaneously. Their methodic planning and perseverance usually lead to their success in their chosen profession. On the other hand, manipulation is considered as one of the behavior's ways among people and it is defined as an asymmetric interaction, where one side take advantage of the other side to accomplish their own goals. It is a way of influencing other people, where their actions are the means of the manipulator to gain what they need. Managing and efficient employees scored low in the level of openness to experience and agreeableness and this is probably the main reason of high predictive power of these personality traits. Low level of openness to experience and agreeableness mean the opposite side of above characterized personality traits. Some limitations should be addressed. First, the selected personality traits were measured by selfreported questionnaires. The second limitation of the study is that only one scale came into use which measured manipulation as a core part of social intelligence. The research identified many helpful attributes for the evaluation of personality traits in relation to manipulation as a core part of social intelligence.

\section{References}


Bozogáňová, M. (2014). Sociodemografické faktory vnímaného bezpečia. In M. Kentoš. (Eds.), Psychologické súvislosti vnimania bezpečia (pp. 19-37). Prešov: Universum.

Buss, D. M. (1996). Social adaptation and five major factors of personality. In J. S. Wiggins (Eds.), The five-factor model of personality: Theoretical perspectives (pp. 180-207). New York: Guilford.

Christie, R. (1970). Why Machiavelli? In R. Christie \& F. L. Geis (Eds.), Studies in Machiavellianism (pp. 1-9). New York: Academic Press.

Edmüller, A., \& Wilhelm, T. (2003). Nenechte sebou manipulovat! jak rozpoznat manipulaci a prosadit svou vi̊li. Praha: Grada Publishing.

Fehr, B., Samsom, D., \& Paulhus, D. L. (1992). The construct of Machiavellianism: Twenty years later. In C. D. Spielberger \& J. N. Buther (Eds.), Advances in personality assessment, (pp. 77-116). Erlbaum: Hillsdale.

Frankovský, M., \& Birknerová, Z. (2012). Etický rozmer sociálnej inteligencie ako výpovednej charakteristiky. In Psychologica XLI: Zborník Filozofickej fakulty Univerzity Komenského v Bratislave (pp. 97-110). Stimul: Bratislava.

Frankovský, M., \& Birknerová, Z. (2014). Zist’ovanie sociálnej inteligencie metodikou MESI- psychometrické charakteristiky. Človek a spoločnost', 17(1), 7-110.

Hřebíčková, M., \& Urbánek, T. (2001). NEO pětifaktorový osobnostní inventář. Praha: Testcentrum.

Jang, K. L., McCrae, R. R., Angleitner, A., Riemann, R., \& Livesley, W. J. (1998). Heritability of facet-level traits in a crosscultural twin sample: Support for a hierarchical model of personality. Journal of Personality \& Social Psychology, 74, $1556-1565$.

Jones, D. N., \& Paulhus, D. L. (2009). Machiavellinism. In M. R. Leary\& R. H. Hoyle (Eds.) Handbook of individual differences in social behavior, (pp. 93-108), New York: Guilford.

Kaukiainen, A., Björkqist, K., Osterman, K., Lagerspetz, K. M. J., \& Forsblom, S. (1995). Pre-estimated social intelligence (PESI). Turku, Finland: Department of Psychology, University of Turku.

Lorincová, T., \& Lelková, A. (2016). Prediction of manipulation, empathy and social irritability through selected personality traits among managers. Periodica Polytechnica Social \& Management Sciences, 24(2), 83-87.

Mayer, J. D. (1998). A Systems framework for the field of personality. Psychological Inquiry, 9(2), 118-144.

McAdams, D. P. (1996). Personality, modernity and the storied self: A contemporary framework for studying persons. Psychological Inquiry, 7(4), 295-321.

McCrae, R. R., \& Costa, P. T. (1987). Validation of the five-factor model of personality across instruments and observers. Journal of Personality \& Social Psychology, 52, 81-90.

McCrae, R. R., Costa, P. T., Jr., \& John, O. P. (1998). Heritabilities of common and measure-specific components of the Big Five personality factors. Journal of Research in Personality, 32, 431-453.

McCrae, R. R., Terracciano, A. (2005). Universal features of personality traits from the observer's perspective: Data from 50 different cultures. Journal of Personality \& Social Psychology, 88, 547-561.

McHoskey, J. (1995). Narcissism and Machiavellianism. Psychological Reports, 77(3), 755-759.

Oravcová, J. (2004). Socialna psychologia. Banská Bystrica: UMB Fakulta humanitných vied.

Smékal, V. (2002). Pozváni do psychologie osobnosti. Brno: Barrister and Principal.

Soldz, S., \& Vaillant, G. E. (1999). The Big Five personality traits and the life course: A 45- year longitudinal study. Journal of Research in Personality, 33, 208-232.

Spurný, J. (1996). Psychologie násili: O psychologické podstatě násili, jeho projevech a zpưsobech psychologické obrany proti пе̌mu. Praha: Eurounion.

Štefko, R., \& Krajňák, J. (2013). An Analytical View on Fine Arts Marketing. Poland, Katowice: The Jerzy Kukuczka Acadeny of Physical Education. 